\title{
多彩な症状を呈した，原発性鎖骨下静脈閉塞症の透析例
}

\author{
芦沢厚志 木村 玄次郎今西 政仁 河野 雄 平 \\ 小嶋 俊一 佐内透倉持衛夫尾前照雄 \\ 安藤 太棌 中島 伸 之* \\ 国立循環器病センター内科 同外科*
}

(平成 1 年 5 月 29 日受付，同年 9 月 8 日受理)

key words : 左鎖骨下静脈閉塞，内シャント，左上半身腫脹

〈要旨〉

症例は 47 歳男性. 左前腕に内シャントを造設後, 徐々に左上半身の腫脹, 静脈怒張が進み, 多彩な症状を呈した。 静脈造影で左鎖骨下静脈閉塞と側副血行路の発達を認め, シャントを結紫したところ左上半身腫脹は軽快し, 新たに 造設した右前腕内シャントを用いて，再び維持透析を続行している症例を報告する。

\section{A case of primary subclavian vein obstruction relieved after binding of arteriovenous fistula}

Atushi Ashizawa, M. D., Genjiro Kimura, M. D., Masahito Imanishi, M. D., Yuhei Kawano, M. D., Shunichi Kojima, M. D., Toru Sanai, M. D., Morio Kuramochi, M. D., Teruo Omae, M. D., Taizo Ando, M. D.*, Nobuyuki Nakajima, M. D.*

Departments of Medicine and Surgery*, National Cardiovascular Center

A 47-year-old man on maintenance hemodialysis developed progressive swelling in the left upper half of his body after an arteriovenous fistula was made in his left arm. Venography showed obstruction of the subclavian vein and rich collaterals. Binding of the fistula resulted in rapid recovery of the various signs of swelling

症例

患者：47歳, 男性

主訴：左上半身の腫脹

既往歴, 家族歴：特記事項なし。

現病歴：35 歳のとき, 検診で高血圧, 蛋白尿, 心拡大 を指摘されたが放置していた. 39 歳頃より，労作時息切 れ，動悸が出現していた。1983 年 11 月，40 歳の時，上 気道炎を契機に夜間呼吸困難が出現し, 当センターを緊 急受診し, うっ血性心不全, 腎不全, 高血圧性心疾患と 診断され，入院となった。心不全は保存的治療により較 快した。腎不全は, 多発性囊胞腎によるものと診断され, 血液透析に導入された。 その際造設した左前腕内シャン トは特に支障なく，退院後しばらくは近医にて外来維持 透析を受ていた。

1985 年 4 月, 42 歳の時, シャント流量が低下したため, 近医にて左前腕内にシャントを再造設したところ，術後 左手指の腫脹が出現し, 以後腫脹は, 左前腕から上腕に

芦沢 厚志 国立循環器病センター内科

干 565 吹田市藤白台 5-7-1(06-833-5012)
広がり，翌年には左前胸部にも出現した。腫脹はさらに 左体幹部, 頸部, 顔面, 頭部と左上半身に及び, 頭重感, 耳閉塞感が出現し，また，時に鼻出血を認めた。1987 年 12 月 2 日, 左上半身腫脹の精査目的で当センターへ再入 院した。

入院時現症：身長 $165 \mathrm{~cm}$, 体重 $54.5 \mathrm{~kg}$. 血圧は右上肢 で 180-110 mmhg.

腫脹は左頭部, 顔面, 頸部, 左上肢, 前胸部, 左腋窩 より，下腹部まで及び，さらに左背部にも広く認められ た。

上肢周囲徑は上腕が，右 $29 \mathrm{~cm}$, 左 $39 \mathrm{~cm}$, 前腕で右 24 $\mathrm{cm}$, 左 $37 \mathrm{~cm}$ で, 左右差は, 上腕で $10 \mathrm{~cm}$, 前腕で 13 $\mathrm{cm}$ であった. 内シャント部には著明なシャント雑音が 聴取され, 左上肢は褐色調で, 硬く腫脹していた。シャ ントより末梢部では，握力の低下，冷感と，表在知覚の 鈍麻を認めた。

入院後経過 : 左上肢静脈造影にて, 左鎖骨下静脈の完 全閉塞を認め,さらに上腕部には豊富な側副血行路があ り, 上は頸部, 頭部へ, 下は胸腹部へ広がる像を認めた 


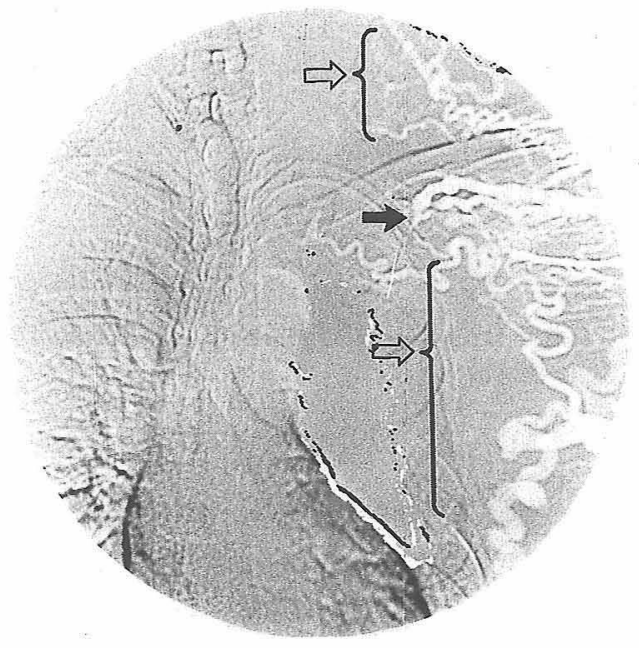

図 1 左鎖骨下静脈造影

$\Rightarrow$ : 閉塞部位

$\Rightarrow$ : 側副血行路

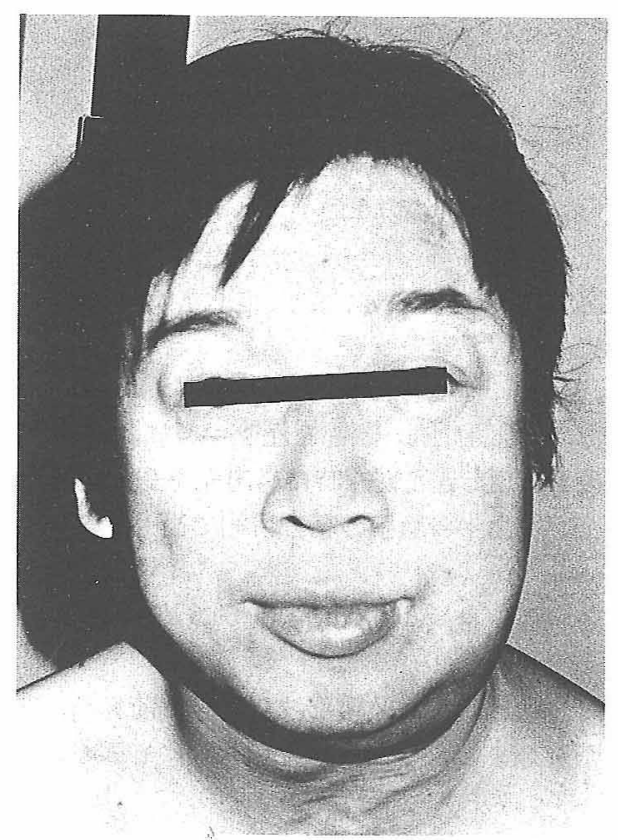

図 2 顔写真 (左シャント結禁術前)

(図 1 )。

左上半身の静脈血のうっ滞は，この閉塞に加え，豊富 なシャント血流によるものと考え，新たに右前腕に内 シャントを造設後，左シャント結禁術を行なった。

術前の顔写真では，左煩部，眼瞼の腫脹，及び左前頭 部に表在静脈の怒張を認めた(図 2 )。術後，左半分の腫

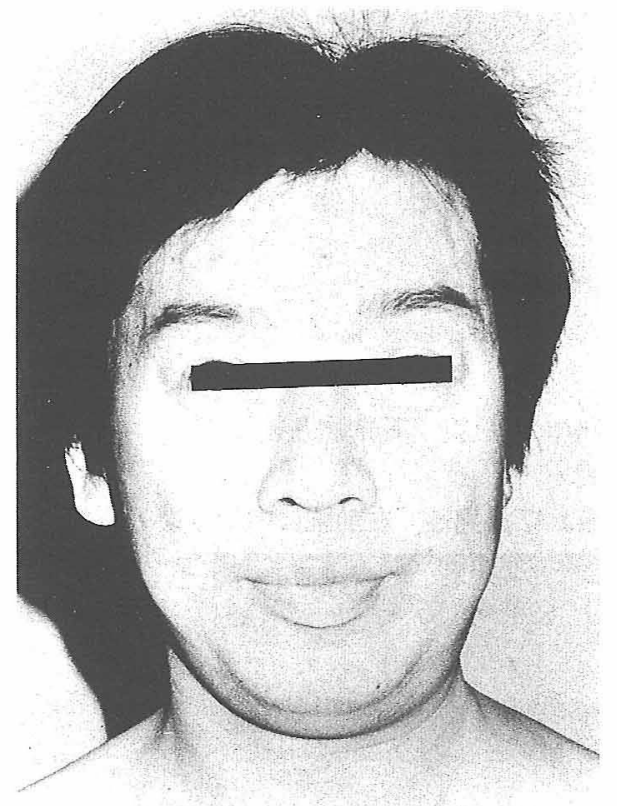

図 3 顔写真 (左シャント結禁術後)

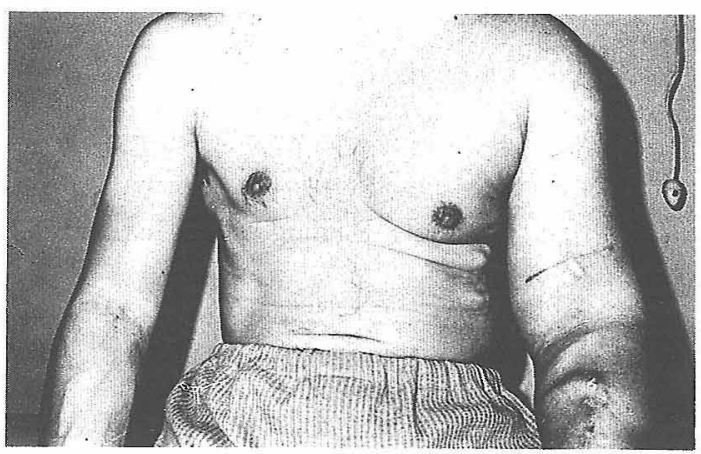

図 4 上半身（左シャント結禁術前）

脤はかなり消失した(図 3 )。術前の上半身では，左上肢 の腫脹が高度であった(図 4)。術後, 腫れはかなり消失 した(図 5 )。術前後の左右上肢の周囲徑差の経過を図 6 に示す。上腕，前腕ともに術直後より，腫脹が軽快傾向 にあり，術後 21 日目の退院時には，上腕では差が $4 \mathrm{~cm}$ ， 前腕では左右差は認めなくなった。

\section{考察}

深部静脈血栓は元来下肢に多く，上肢には希であ る ${ }^{1,2)}$ : 本症は透析患者であり，内シャントによる静脈血 流量の増大が鎖骨下静脈閉塞症の症状を増悪させていた と考えられる極めて希な例であった。原発性鎖骨下静脈 閉塞症（または血栓症）は，19 世紀後半に Paget や Schroetter が報告しておう，1949 年, Hughes により 


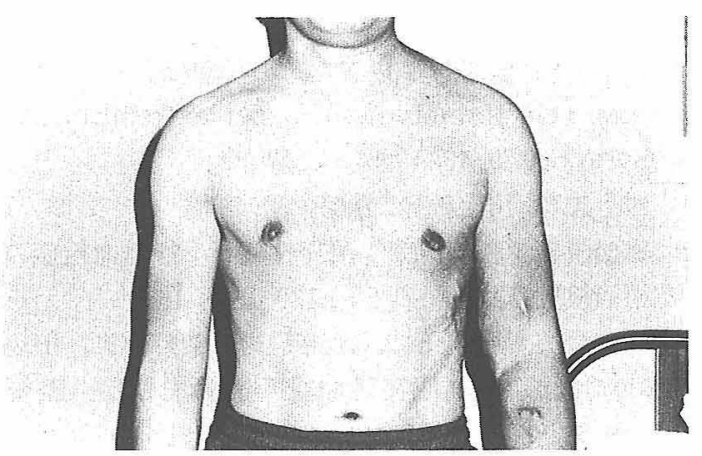

図 5 上半身 (左シャント結禁術後)

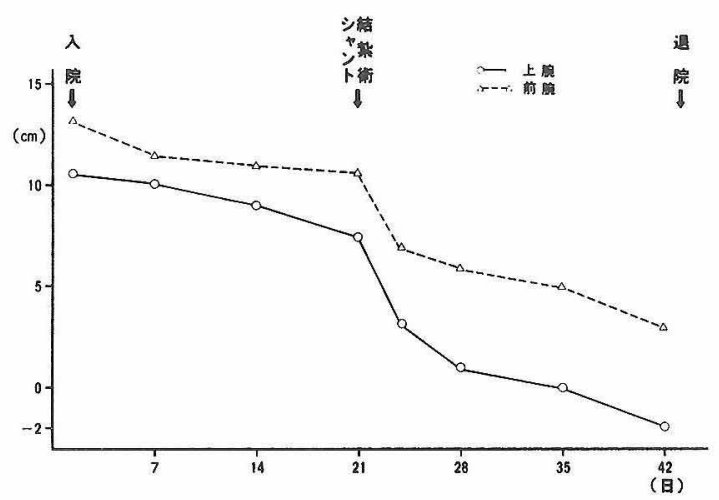

図 6 人院より退院までの左右上肢の周径差

Paget-Schroetter 症候群と命名されだ2。原因には諸説 があるが，実際には不明瞭な例が多い。特に鎖骨下静脈 が，その周囲との位置関係並びに頸部，肩甲部，上肢の 労作が加わり，慢性の血管内腔障害を来たし血栓形成に つながる，いわゆる圧迫説が提唱されている4

血液透析に関連した鎖骨下静脈狭窄症については，緊 急時の blood access などの目的で行なわれる鎖骨下静 脈穿刺及びカテーテル留置が発症誘因として考光られて いる7。本例では，カテーテルは留置をされていない。ま た外傷，腫瘍，感染等のエピソードもなく，原因不明で ある。症状としては，いわゆる左上肢に腫脹，チアノー ゼ，静脈怒張の三主徴がある他，左上半身，特に耳介， 眼瞼，顔面，頸部，側胸腹部，背部にも及んでいた点で， 極めて多彩であった。

発症機序として考えられることは，原因不明の鎖骨下 静脈閉塞症が存在し, 自然経過のうちに側副血行路が発 達し，豊富なシャント血流（恐らく，一回目に作成した シャントの血流は比較的乏しく，二回目のそれはかなり 豊富であったと考えられる) の出現により，左上肢及び 側副路の血流量の増大を来たし，諸症状が出現したと考 えた。側副路は，左上腕部から，一部は肩，頸部より頭

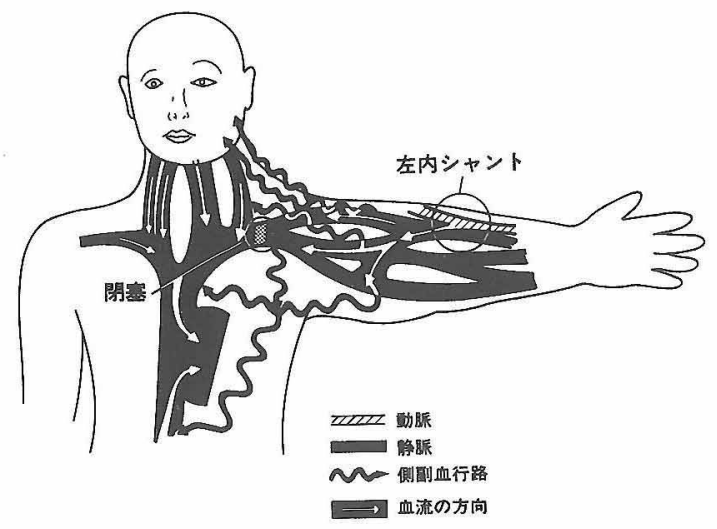

図 7 予想される静脈系の血行動態と発 症機序（左シャント結紮術前） 頭部静脈系のうつ血症状 (腫脹, 頭痛, 左眼瞼浮 腫，鼻出血），左頸部から肩甲部，背部にわたる腫 脹, 左頸静脈の怒張, 左上肢の腫脹, 左腋窩, 胸 腹部の腫脤と表在静脈の怒張を認める。

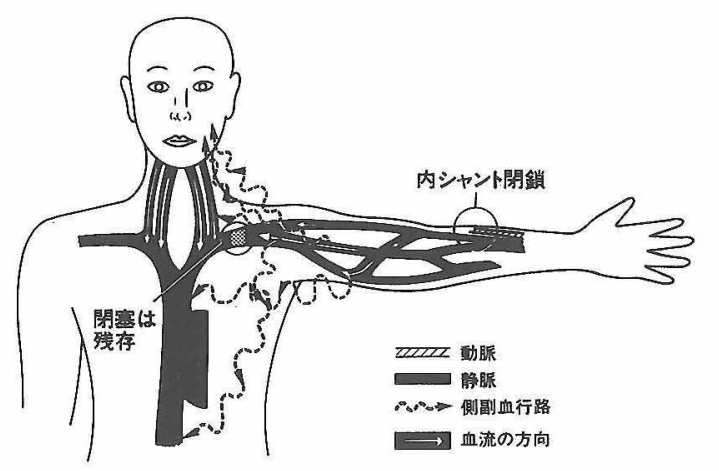

図 8 (シャント結禁後) 諸症状は軽快した

部顔面の静脈系に通じ，同部位の静脈系のうつ血症状が 現われ，また一部は腋窩，胸腹壁に及び，同部位の腫脹， 表在静脈の怒張を来たしたものと考えた(図 7)。同シャ ントを結禁したところ，諸症状は速やかに軽快傾向と なった(図 8)。この事実が逆に，本症とシャントとの関 係を裏付ける結果となった。鎖骨下静脈閉塞が残存して いても, シャント血流が存在しない限り，側副血行路に より，循環障害が代償されうるものと考光た。

治療法について，理想的なものは未だ統一見解を見て いない。血栓症の急性期であれば，抗凝固療法帛や Fogaty カテーテルによる血栓摘除9,10)を試みる価值が あるが，本例は発症よりかなり経過しているので，適応 外である。また血行再建術として, 自家静脈 patch を用 いた方法 ${ }^{5,6)}$ 等, 外科的アプローチの他, 最近は PTA (perctaneous transluminal angioplasty) ${ }^{7}$ をを推奨する 
施設もある、本例では，さしあたりシャントを結禁する ことで, 症状の軽減を認めている。

\section{結語}

44 歳, 男性, 血液透析患者で, 原因不明の左鎖骨下静 脈閉塞症に対し, 左前腕に内シャントを造設したところ, 左上半身に特異な浮腫が発現した, 珍しい症例を経験し たのでここに報告した。

本論文の要旨は第 32 回日本透析療法学会 (1988 年 7 月, 名 古屋）において発表した。

\section{文献}

1) Barker N W, Nygaard K K, Walter W, Priestley $\mathrm{J} T$ : Statistical study of postoperative venous thrombosis and pulmonary embolism. Proc Staff Meet Mayo Clin 16 : 33-37, 1941

2) Featherstone $T:$ Spontaneous subclavian vein thrombosis : Scott Med J 33 : 270-271, 1988

3) Hughes E S R:Collective review, Venous obstruction in the upper extremitry (Paget -Schroetter syndrome). A review of 320 cases.
Internat Abstr Surg 88: 89-127, 1949

4) Adams J T, McEvoy R K, DeWeese J S : Primary deep vein thrombosis of upper extremitry. Arch Surg $91: 29-42,1965$

5）村上忠司, 川上敏晃, 飯塚栄治, 高橋 浩, 高橋 透, 磯松俊夫, 杉江三郎：原発性鎖骨下静脈血栓症の手 術治検例。臨床外科 $25: 130-135,1970$

6) 高橋 透, 渡辺正二, 浜野哲男, 柴野信夫, 田辺達 三, 川上敏晃：原発性鎖骨下静脈血栓症.脈管学 $17: 627-633,1977$

7) Scwab S J, Quares L Darryl, Cohan R H, Saeed M, Dennis VW : Hemodialysis-associated subclabian vein thrombosis. Kidney Int $33: 1156-1159$, 1988

8) Coon W W, Willis P W : Thrombosis of axillary and subclavian veins. Arch Surg 14:657-633, 1967

9）赤尾元一, 徳永正晴, 四宮 衛, 真弓久則：原発性 鎖骨下静脈血栓症．臨床胸部外科 $3: 92-96,1983$

10）岡本好史, 林真, 田苗英次, 黄 秋雄, 渡辺 裕, 松田光彦：原発性鎖骨下静脈血栓症の手術治験例. 外科診療 $18: 91-94,1976$ 